years 1915-1917, the ether tremor only occurred in five cases. In this war hospital, recently opened, out of 41 operations performed under "open "ether anæsthesia, the tremor has occurred in three cases, not during induction, bnt after the establishment of full anæsthesia when the patient has been allowed to revert to a lighter degree of narcosis. Is it possible that active service under modern conditions may, in certain cases, induce a nervous condition favourable to the tremor? I first saw the phenomenon at Addenbrooke's Hospital, in 1880, when the late Sir George Humphry was amputating a leg. He was about to tie the vessels when the stump began to shake with great violence. Turning to the students, he remarked, "Gentlemen, this is a complication which I have never experienced before. Let us wait till it stops." Humphry had then about 30 years' experience of operations under anæsthetic, and it is rather remarkable that the condition had not already come under his observation.-I am, Sir, yours faithfully,

Fusehill War Hospital, Carlisle, Dec. 11th. 1917

W. D. ANDERSON.

\section{THE SURGERY OF EXOPHTHALMIC GOITRE.}

To the Editor of THE LANCET.

Sir,-In Lieutenant. -Colonel T. P. Dunhill's paper on exophthalmic goitre, which appeared in your issue of Dec. 15th, there is much of interest, and more of common-sense than usually appears in surgical pronouncements on the subject. The article naturally and necessarily contains several references to Robert McCarrison's recently-issued work on the thyroid gland. As the author is either in India or on the high seas, it would be a long time before he cunld receive the issue of THE LANCET and a very long time before you could receive his reply; and as I am not only intimately acquainted with his views, but am in a humble sense the literary godfather of the clinical portion of his book, 1 make no apology for claiming the right to speak for him in his absence. There is nothing so vapid as a belated rejoinder.

By way of prompt rejoinder I cannot do better than point out that there is nothing in Colonel Dunhill's article which could in any way modify the validity of the following paragraph, which occurs on p. 240 of McCarrison's book :-

There is no reason to doubt but that a sufficiently extensive thyroidectomy such as is practised by Dunhill will mitigate those symptoms which may be due to hyperthyroidism on the one hand, or to perversion of the thyroid's secretion on the other. But we must realise the limitations of such an operation and not seek to credit it with the cure of a malady the cause of which it leaves untouched. Nor should the possibility of the subsequent appearance of thyroid deficiency be overlooked. In the present state of our knowledge such an extensive thyroidectomy may be the best we can do in a small proportion of cases, hut if it must be done let"it be done only when all else fails, and let its results be recorded with scientific p'ecision.

Neither is there anything in Colonel Dunhill's article to which any reasonable physician could object. Briefly expressed, his message seems to be that an operation on the thyroid gland in Graves's disease is not only justifiable but obligatory when the symptoms become urgent. With this we can all afford to agree; McCarrison's point is that the symptoms would never arrive at that stage if the disease were properly treated in its earlier stages; that, if the "medical filter" did its work properly, the knives of the thyroidectomist would rust from disuse. With much less emphasis than the occasion would seem to warrant, McCarrison says :-

$I$ believe that surgery has a more rational place in the treatment of this disease than that of interference with the chyroid gland-namely the correction of such conditions as chronic appendicitis, chronic gall-bladder infammation, chronic septic tonsillitis, gastro-intestina stagnation or other disorders which may obviously be benefited by it For of what use would it have been to have removed the major part of the girl's thyroid, whose case we have considered in an earlier part of this section, and to have lelt her with such a degree of gastric atagnation as $\mathrm{X}$ ray examination revealed? Such an operation might have improved her condition temporarly, but without the correction of the stagnation it could not have restored her to health.

Lord Palmerston is credited with the remark that nothing could be more misleading than figures, except facts. In connexion with Graves's disease it is the unfortunate fashion to quote the figures of a physician who claimed as a proud fact that 50 per cent. of his cases were cured by ordinary medical means. I bave not at the moment an opportunity of searching the records to discover the date on which these glad tidings of great joy were conveyed to a goitrous generation; but if there be a physician of to-day who by ordinary medical means cannot cure more than half the cases of exophthalmic goitre which come under his care, I can confidently recommend him to forsake medicine and take to surgery-or even to skittles

I am, Sir, yours faithfully,

Harley-street, W., Dec. 15th, 1917. LEONARD WILLIAMS.

\section{THE FUTURE OF THE POOR-LAW.}

\section{To the Eaitor of THE LANOW'.}

SIR,-To my letter in THE LANCET of Nov. 17th under this heading I have had 114 replies. The question I asked was: "Do you wish the Poor-law to be merged into the present or future Insurance Act?" Two only of my correspondents answer "Yes." I have had 400 replies to a previous questionnaire, all saying that they do not wish for the proposed absorption of their service. There are about 5000 Poor-Law medical officers, the majority of whom must wake up if the wishes of the service are to be stated at all adequately. So far 500 members are practically unanimously against the notion of absorption.

I am, Sir, yours faithfully,

\section{A. Withers Green,}

Honorary Secretary, Poor-law Medical Officers' Association. Wardrobe-place, London, E.C. 4.

\section{THE SERVICES.}

\section{ROYAL NAVAL MEDICAL SERVICE.}

David MeM. Dickson to be temporary Surgeon.

\section{ROYAL ARMY MEDICAL CORPS.}

Temp. Capt. F. F. Muecke relinquishes the acting rank of Lieutenant-Colonel on reposting.

Temporary Lieutenants to be temporary Captains: A. W. P. Pirie, J. Paterson, J. R. Fleming, D. O. Richards, W. C. P. Barrett, G. O'N. Waddington, T. P. Lineham, L. G. White, M. Golding, W. Simpson, Waddington, T. P. Lineham, L. G. White, M. Golding, W. Simpson,
J. B. Lester, V. C. Montgomery. A. H. Macklin, W. D. Kirkwood, J. B. Lester, V. C. Montgomery A. H. Macklin, W. D. Kirkwood,
F. A. Godson, E. W. Hall, J. J. O Mullane, W. M. G. Guinness, B. G.H. Connolly, C. L. Warke.

Temp. Hon. Lieut. C. G. Hitchcock to be temporary honorary Captain.

Officers relinquishing their commlssions : Temp. Capts. J. B. Scott (on appointment under the Ministry of National Service), F. A.
Anderson, M.C., D. Macnish, P. M. Ragg. A. F. Filliott, A Burns, Anderson, M.C., D. Macnish, P. M. Ragg, A. F. Mlliott, A Burns,
C. W. Ensor, H. A. Cutler, W. Jameson, A. R. Muir, R. W. Thomas, C. W. Ensor, H. A. Cutler, W. Jameson, A. R. Muir, R. W. Thomas, T. Davidson, A. J. Couper, C. C. Bullmore, F. W. Wynne, K. J. Aveling, G. Pollock, F. J. McGlade, R. S. Jenkins, T. W. G. Hogg,
L. J. H Oldmeadow, J. E. R. Orehard, J. J. Anning, A. J. Anderson (on account of ill-health), G. B. Flux (on account of ill-health). Temp. Lieuts.: W. T. Morton, W. L. Wulker, T. B. Stedman, J. B. MeEwan, R. C. de Ö. Wheeler.

SPECIAL RESERVE OF OFFICERS.

Lieutenants to be Captains : R. V. Olarke, W. Yeoman, M. A. White, s. C. Swinburne.

\section{TERRITORIAL FORCE.}

Major G. Hall, C.M.G., is restored to the establishment

Capt. (temp. Major, acting Lieut.-Col.) W. D. Sturrock reverts to the temporary rank of Major on ceasing to command a Field Ambulance.

Capt. J. Gracie is seconded.

Capt. C. A. Moore is seconded.

Capt. J. H. Bald win resigns his commission on account of ill-health, and is granted the honorary rank of Captain. TERRTTORIAL FORCE RESERVE

Surgeon Lieut.-Col. (Bon. Surgeon Col.) T. McC. Foley, from R.F.A., to be surgeon Lieutenant-Colonel.

Col. S. S. Hoyland, from A.M.S., to be Colonel.

Lieut.-Col. E. J. Lawless, from Field Ambulance, to be LieutenantColonel.

Lieut.-Colonel W. B. Cockill, from Casualty Clearing Station, to be Lieutenant-Colonel.

Lieut.

Lieut-Col $T$ T Collins, from Field Ambulance, to be Lientenant Colonel.

Major J. J. Cox, from General Hospital, to be Major.

Major R. Starkey-Smith, from Field Ambulance, to be Major.

Major C. W. Goddard, from Sanitary Company, to be Major.

The undermentioned officers from attached R.A.M.C.:-To be Major The undermentioned officers from attached R.A.M.C. :-To be Major:
Major R. E. Williamson. To be Captains : Capts. F. W. Goodbody, W. E. L. Filliott, and J. Wallace (from Field Ambulance).

\section{TERRITORIAL DECORATION.}

The King has conferred the Territorial Decoration upon the undermentioned offisers :-London Regiment: Lieut.-Col. J. Godding (temporary Lieutenant-Colone1, A.M.S.). Royal Army Medical Corps Lieut.-Col. E. T. Collins, Major (temp. Lieut.-Col.) A. F. Swanson, Lieut.Col. C. E. Humphreys, Major D. Walker, Major J. B. Bates,

Munificent Gift to Cardife Medical Schoot. Miss Talbot, of Margam Abbey, Port Talbot, Glamorgan has presented $\{30,000$ to the Welsh Medical School, Cardiff, for the foundation of a Chair of Preventive Medicine. 